\title{
Reelin Does Not Directly Influence Axonal Growth
}

\author{
Yves Jossin and André M. Goffinet \\ Neurobiology Unit, University of Namur School of Medicine, B5000 Namur, Belgium
}

Reelin is a large extracellular glycoprotein involved in the development of architectonic patterns, particularly in the cerebral cortex and hippocampus, where it is synthesized primarily by Cajal-Retzius cells. In the hippocampus, Reelin also regulates the growth and/or distribution of afferent entorhinal and commissural axons. To assess further the possible action of Reelin on axonal growth, we used the three-dimensional collagen gel assay to measure axonal elongation from reeler cortical explants in the presence of Reelin. Because Reelin is proteolytically processed in vivo, normal explants and Reelin-transfected human embryonic kidney 293T cells were used, respectively, as sources of processed and full-length protein. The reliability of the assay was tested by demonstrating a clear repulsive action of semaphorin 3F $(p<0.0001)$. However, neither full-length nor processed Reelin exhibited any significant attraction or repulsion on cortical axons. Our results suggest that the reported effects of Reelin on axonal pathways are indirect, secondary to the architectonic disturbances that result from Reelin deficiency, and that the effects of Cajal-Retzius cells on connectivity are primarily independent of Reelin.

Key words: Reelin; axon guidance; collagen gel assay; cortical explants; hippocampus; Cajal-Retzius cells
Reelin, the extracellular glycoprotein defective in reeler mutant mice (D’Arcangelo et al., 1995), plays a key role in architectonic brain development (for review, see Lambert de Rouvroit and Goffinet, 1998). In the embryonic cortex and hippocampus, Reelin synthesized by neurons in the marginal zone, including CajalRetzius (CR) cells, acts locally on end-migration neurons of the cortical plate and instructs their radial organization. At the surface of target cells, Reelin binds to two lipoprotein receptors, very-low-density lipoprotein receptor (VLDLR) and apolipoprotein $E$ receptor 2 (ApoER2), which relay the signal into the cell via the adapter Dab1 (Bar and Goffinet, 1999; Cooper and Howell, 1999; Trommsdorf et al., 1999). In addition to their Reelindependent effect on neuronal patterning, hippocampal CR cells were shown to guide entorhinal axons to the stratum lacunosum moleculare of the hippocampus, and perturbation experiments with the Reelin-blocking antibody CR50 suggested that Reelin may play a part in this guidance (Del Rio et al., 1997). However, observations that hippocampal afferents successfully reach their target in reeler mice, although with a significant delay (Borell et al., 1999a,b; Deller et al., 1999), suggest that other factors produced by CR cells are more important than Reelin, which could serve to promote collateral branching in terminal fields rather than guide entorhinal axons. Whether the developmental delay of hippocampal afferents in reeler mice reflects a direct action of Reelin on axonal growth or is secondary to the profuse architectonic malformation remains unclear. To study that question, the action of Reelin on cortical axonal growth was studied in vitro using the three-dimensional (3D) collagen gel assay. Because

Received April 30, 2001; revised Aug. 27, 2001; accepted Sept. 4, 2001.

This work was supported by Contract 3.4533 .95 from the Fonds de la Recherche Scientifique Médicale, by Contract 94/99-186 from the Association pour la Recherche sur le Cancer, and by the Fondation Médicale Reine Elisabeth. Y.J. is supported by the Fonds de Recherche pour l'Industrie et l'Agriculture. We thank C. Métin and Z. Molnar for advice with the collagen assay, M. Tessier-Lavigne for the gift of the semaphorin plasmids, E. Depierreux for statistics, and M. Frotscher and F. Polleux for discussion.

Correspondence should be addressed to André M. Goffinet at the above address. E-mail: Andre.Goffinet@fundp.ac.be.

Copyright (C) 2001 Society for Neuroscience 0270-6474/01/210001-04\$15.00/0
Reelin is cleaved in vivo, probably by a metalloproteinase (Lambert de Rouvroit et al., 1999), and the physiological consequences of this processing are unknown, the actions of both the full-length and the processed form of Reelin were analyzed. Neither form of the protein displayed a significant repulsive or attractive effect on axonal outgrowth. Although these observations cannot exclude a direct action of Reelin solely on a subset of axons, they strongly suggest that the observed disturbances of axonal growth in Reelin-deficient mice are secondary to the brain malformation in the mutant, possibly including disturbances of some recently described projections from CR cells (Ceranik et al., 1999).

\section{MATERIALS AND METHODS}

Explant culture. Normal BALB/c and homozygous reeler (Reln, Orleans allele) mice were used. Pregnancies were dated by checking females for the presence of a vaginal plug; the day of the plug was noted as embryonic day 0 (E0). Mice were killed by cervical dislocation and the embryonic brains were removed under cold anesthesia. Experiments were performed in accordance with National and Institutional Guidelines for animal care and were approved by the competent Animal Ethics Committee. To obtain cortical explants, the dorsal tiers of the hemispheres were dissected, meningeal membranes were pealed off, and the tissue was cut into $300 \mu \mathrm{m}$ explants with a McIlwain tissue chopper (Campden Instruments, Leicester, UK).

Explants (E14-E18) were cultured in three-dimensional collagen gels as described previously (Lumsden and Davies, 1983; Toran-Allerand, 1990). Briefly, explants were embedded in $20 \mu \mathrm{l}$ of collagen [9 parts rat-tail collagen, 0.9 parts $10 \times$ Eagle's medium with L-glutamine (Life

This article is published in The Journal of Neuroscience, Rapid Communications Section, which publishes brief, peerreviewed papers online, not in print. Rapid Communications are posted online approximately one month earlier than they would appear if printed. They are listed in the Table of Contents of the next open issue of JNeurosci. Cite this article as: JNeurosci, 2001, 21:RC183 (1-4). The publication date is the date of posting online at www.jneurosci.org.

http://www.jneurosci.org/cgi/content/full/5827 


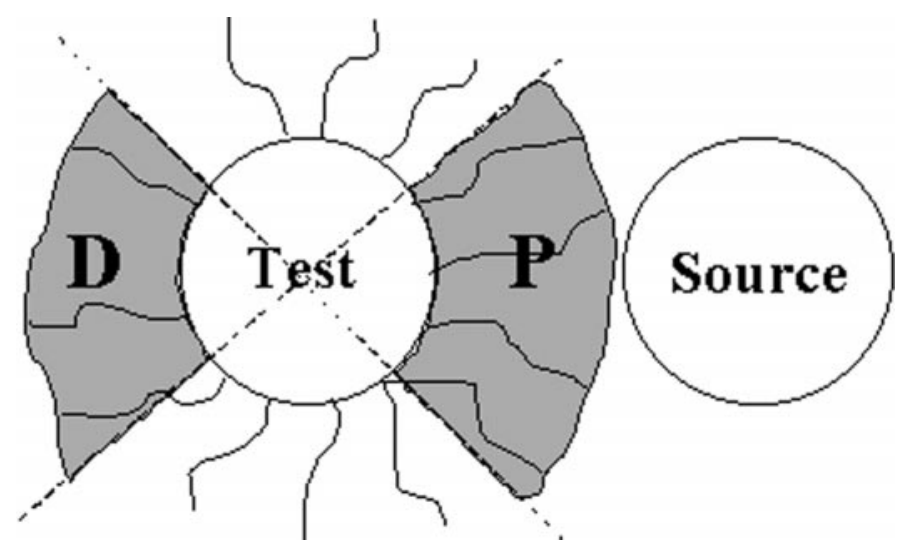

Figure 1. Collagen gel assay for analysis of axonal outgrowth from a test reeler explant in the presence of a source of Reelin, either a normal explant or transfected cells, or in the presence of control cells. The ratio of the proximal $(P)$ versus distal $(D)$ areas covered with axon outgrowth is used as an index for statistical analysis.

Technologies, Grand Island, NY), and 0.1 parts 0.08 mм $\mathrm{NaHCO}_{3}$ in 0.1 $\mathrm{M} \mathrm{NaOH}$ ) in culture dishes. The explants were positioned at a distance of $300-500 \mu \mathrm{m}$ from each other or from cell pellets. The dishes were then placed in an incubator at $37^{\circ} \mathrm{C}$ for $30 \mathrm{~min}$ to gelify the collagen, before being covered with culture medium [Eagle's medium with L-glutamine, $0.1 \%$ penicillin-streptomycin, Fisher's cocktail $(1 \mathrm{mg} / \mathrm{ml}$ BSA, $1 \mathrm{mg} / \mathrm{ml}$ transferrin, $10 \mu \mathrm{g} / \mathrm{ml}$ aprotinin, $600 \mathrm{~nm}$ sodium selenite, and $250 \mu \mathrm{g} / \mathrm{ml}$ insulin), and 5\% horse serum] as described previously (D'Arcangelo et al., 1997).

Reelin and semaphorin production in human embryonic kidney 2937 cells. Human embryonic kidney $293 \mathrm{~T}$ cells were transfected with the Reelin cDNA construct pCrl (D'Arcangelo et al., 1997), a Myc-tagged semaphorin 3A construct, or a Myc-tagged semaphorin 3F construct (provided by M. Tessier-Lavigne, University of California, San Francisco, CA). Cells were seeded at $3 \times 10^{5}$ cells per $35 \mathrm{~mm}$ well and transfected 16-20 hr later with $2 \mu \mathrm{g}$ of Reelin cDNA using Lipofectamine $(10 \mu \mathrm{l}$ in $1 \mathrm{ml}$ of opti-MEM; Life Technologies). After $5 \mathrm{hr}$, the supernatant and cell debris were removed and $2 \mathrm{ml}$ of culture medium was added (Iscove's modified Dulbecco's medium with $10 \%$ heat-inactivated fetal bovine serum, all from Life Technologies). Pellets of transfected 293T cells were produced with the hanging-drop method (Métin et al., 1997). At $12 \mathrm{hr}$ after initiation of transfection, cell layers were detached with trypsin, washed twice, and suspended in culture medium with $1 \%$ serum (40 $\mu \mathrm{l}$ per $35 \mathrm{~mm}$ well). Drops $(20 \mu \mathrm{l})$ of the cell suspension were placed on the lids of $35 \mathrm{~mm}$ dishes, which were inverted over dishes containing $2 \mathrm{ml}$ of medium. Hanging-drop cultures were incubated for $14-16 \mathrm{hr}$, after which the cell pellets were harvested into explant culture medium and embedded in collagen.

Quantification of axon growth. Axon growth was quantified by examination and photography under phase contrast or after immunostaining with an anti-neurofilament $200 \mathrm{kDa}$ antibody (clone RT97; Boehringer Mannheim, Mannheim, Germany); analysis of results showed that both methods were comparable. To avoid the possible effects of endogenous Reelin, target explants were all from reeler mice. The zone surrounding target explants was divided into quadrants, thus defining a proximal and a distal quadrant in relation to the source of Reelin (either cell pellet or normal explant), as schematized in Figure 1 . The area covered by the neurites growing from the target explant was measured in the proximal and distal quadrants using Scion Image software (available from http:// rsb.info.nih.gov/nih-image). The ratios of the proximal and distal areas were compared using Student's $t$ test after logarithmic transformation and verification of homogeneity of variance (Bartlett test).

\section{RESULTS}

To verify that normal cortical explants and transfected $293 \mathrm{~T}$ cells expressed Reelin in the 3D collagen gel culture, supernatants were tested by Western blot analysis with the G10 monoclonal antibody, directed against the N-terminal region of Reelin (de Bergeyck et al., 1997). As shown in Figure 2, transfected $293 \mathrm{~T}$

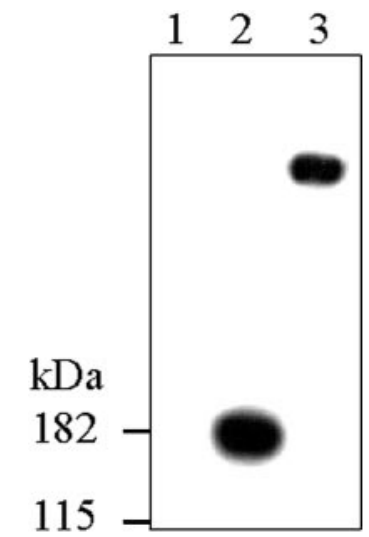

Figure 2. Reelin protein expression, revealed by Western blot analysis with antibody G10. Lane 1, Control, nontransfected cells. Lane 2, Normal cortical explants (E17) primarily produce processed Reelin, the N-terminal $180 \mathrm{kDa}$ fragment of which is revealed with G10. Lane 3, Reelin-transfected 293T cells primarily produce full-length Reelin. Markers are shown in kilodaltons.

cells secreted a full-length Reelin of $\sim 400-450 \mathrm{kDa}$, whereas normal explants primarily produced processed Reelin, as evidenced by the demonstration of a predominant $180-200 \mathrm{kDa}$ N-terminal fragment. Control reeler explants (de Bergeyck et al., 1998) and untransfected $293 \mathrm{~T}$ cells did not secrete any Reelin. These two situations were used to study the effect of full-length and processed Reelin on axonal outgrowth. Similarly, the secretion of semaphorin $3 \mathrm{~A}$ and semaphorin $3 \mathrm{~F}$ in the supernatants of transfected cells was verified using anti-Myc antibodies. Both semaphorin $3 \mathrm{~A}$ and semaphorin $3 \mathrm{~F}$ were detected as full-length $(95 \mathrm{kDa})$ and processed products, namely a $60 \mathrm{kDa} \mathrm{C}$-terminal fragment for semaphorin 3A and two fragments of $60 \mathrm{kDa}$ and 35 $\mathrm{kDa}$ for semaphorin 3F (Adams et al., 1997).

To assess the effect of Reelin on cortical axons, target reeler explants were cultured next to normal cortical explants, used as a source of processed Reelin, or next to a pellet of transfected 293T cells, used as a source of full-length Reelin (Fig. 3). Recombinant Reelin binds to both ApoER2 and VLDLR receptors and triggers the phosphorylation of the Dab1 adapter, suggesting that it is biologically active (Cooper and Howell, 1999; Trommsdorf et al., 1999) (data not shown). In cultures, the control situation consisted of two reeler explants or a reeler explant cultured next to nontransfected cells. To get a positive control of the assay, the effects of semaphorin $3 \mathrm{~A}$ and semaphorin $3 \mathrm{~F}$ were tested. After $3 \mathrm{~d}$ in vitro, axonal outgrowth from the reeler explant was analyzed as described above (Fig. 1). The following situations were analyzed: 29 instances of reeler explants facing Reelintransfected 293T cells (Fig. 3A), 36 instances of reeler versus normal explants (Fig. 3B), 15 control experiments of reeler-reeler co-explants, 12 experiments with reeler explants facing nontransfected 293T cells, 26 instances of normal explants facing semaphorin 3A-transfected cells (Fig. 3C), and 25 instances of normal explants facing semaphorin 3F-transfected cells (Fig. 3D). The results of the statistical analysis are shown in Table 1 . Whereas a significant repulsive action of semaphorin $3 \mathrm{~F}$ on cortical axons was evident $(p<0.0001)$, no repulsion was exerted on cortical axons by semaphorin $3 \mathrm{~A}$ in this system. The axonal outgrowth from reeler explants was not statistically different when the explants faced sources of full-length Reelin (transfected cells), sources of full-length Reelin (normal explants), or Reelindeficient sources (reeler explants or untransfected cells). 

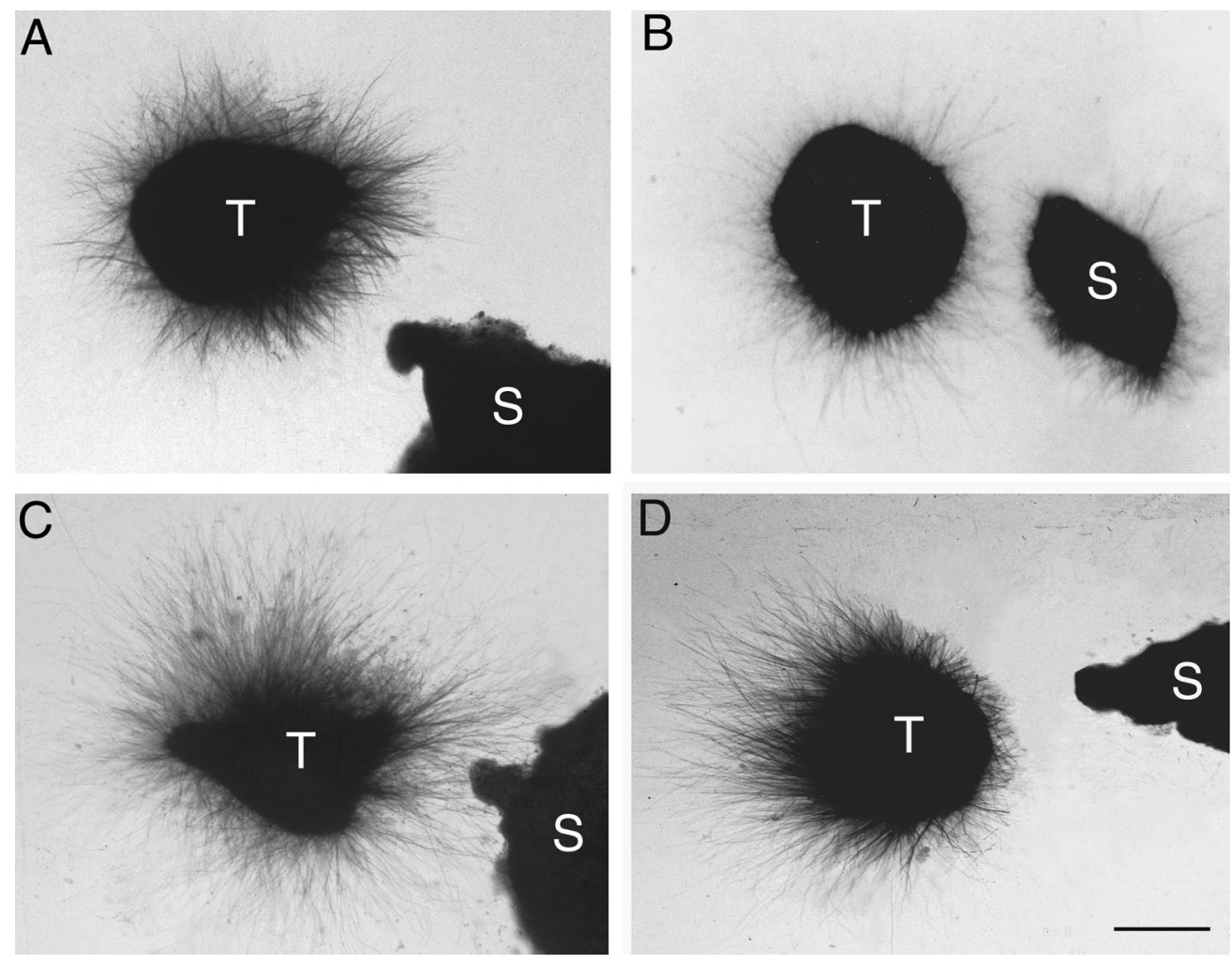

Figure 3. Examples of axonal growth in collagen gel culture assays. $A$, A Reeler explant $(T)$ near a pellet of Reelin-transfected cells as the source $(S)$. B, A Reeler explant $(T)$ near a normal explant as the source $(S)$. $C$, Normal explant $(T)$ near a pellet of semaphorin 3A-transfected cells $(S)$. $D$, Normal explant $(T)$ near a pellet of semaphorin 3 F-transfected cells $(S)$. A repulsive action is clearly seen. Scale bar, $150 \mu \mathrm{m}$.
Table 1. Results of coculture experiments

\begin{tabular}{llll} 
Coculture condition & $n$ & $\begin{array}{l}\text { Mean log } \\
(\mathrm{P} / \mathrm{D})\end{array}$ & Result \\
\hline Reeler/Reelin-transfected & & & \\
$\quad$ cells & 29 & -0.0147 & $\mathrm{NS}$ \\
Reeler/normal & 36 & -0.1415 & $\mathrm{NS}$ \\
Reeler/reeler & 15 & 0.0967 & $\mathrm{NS}$ \\
Reeler/untransfected cells & 12 & 0.0297 & $\mathrm{NS}$ \\
$\quad \begin{array}{l}\text { Normal/semaphorin } \\
\quad \text { 3A-transfected cells }\end{array}$ & 26 & -0.1566 & $\mathrm{NS}$ \\
$\quad \begin{array}{l}\text { Normal/semaphorin } \\
\quad \text { 3F-transfected cells }\end{array}$ & 25 & -0.5267 & $p<0.0001$ \\
\hline
\end{tabular}

Data are analyzed by comparing axonal outgrowth in proximal (P) and distal (D) quadrants as shown in Figure 1 and described in Materials and Methods. $n$, Number of experiments; NS, not significant.

\section{DISCUSSION}

This study was undertaken following evidence that CR cells and possibly Reelin play a permissive role during the development of the entorhinohippocampal pathway (Del Rio et al., 1997). These findings suggested that, in addition to its well-known role in neuronal migration and architectonic patterning, Reelin may also regulate aspects of axonal growth and guidance (Gosh, 1997). The present results show that the outgrowth of axons from reeler cortical explants was not significantly influenced by the presence of full-length or proteolytically processed Reelin; therefore, Reelin does not appear to have any direct attractive or repulsive action on cortical growth cones, at least in vitro. The collagen gel assay (Lumsden and Davies, 1983) has been used successfully in various settings and its sensitivity is considered high (Métin et al., 1997; Chédotal et al., 1998). That the negative result obtained with Reelin is not attributable to a lack of sensitivity of the setup is also demonstrated by the clear-cut axonal repulsion exerted by semaphorin 3F. The somewhat unexpected absence of repulsion by semaphorin $3 \mathrm{~A}$ may be related to the cells used for transfection, as indicated by the observation of different cleavage products for semaphorin 3A and semaphorin 3F (Adams et al., 1997).

The absence of detectable effects of Reelin shows that the protein does not exert any general direct influence on the guidance and growth of cortical axons. Thus far, Reelin has been shown to affect solely the distribution of commissural and entorhinal afferent axons to the hippocampus. Because the explant system examines outgrowth from several types of axons and thus is not selective, our data cannot rule out a direct effect of Reelin on a specific set of axons at a given developmental time. This reservation being made, our results are generally in agreement with other observations that suggest that the actions of Reelin on axonal pathways are likely indirect, secondary to its primary effect on architectonic patterning, and that the hodological effects of CR cells are primarily independent of Reelin. Studies in organotypic slice cultures showed that the ablation of CR cells prevents the ingrowth of entorhinal fibers. Interference with Reelin using the CR50 antibody has a less drastic effect: it does not prevent ingrowth of entorhinal fibers but reduces their branching and collateral expansion in the hippocampal target field (Del Rio et al., 1997; Borrell et al., 1999a). Similarly, entorhinal fibers reach their hippocampal target in Reelin-deficient mice, although with a significant delay, but they fail to form a normal contingent of collaterals and synapses (Borrell et al., 1999b). In addition, hippocampal commissural fibers in reeler mice disperse broadly in the stratum lacunosum moleculare, but they are strictly segregated in normal mice. This anomaly is correlated with the different distributions of CR cells and granule neurons in reeler versus normal mice (Borrell et al., 1999a,b; Deller et al., 1999). The observation that hippocampal CR cells project to the entorhinal cortex suggests that their processes may play a direct role in 
guiding entorhinal fibers to the hippocampal marginal zone. Surely, even if such actions are dependent on Reelin, they cannot be detected in collagen gel assays in which anatomical connections between explants are not present. Together, these studies suggest that the prominent effects of CR cells on the growth of entorhinal afferents to the hippocampus are not primarily attributable to Reelin; in addition, the present observation that Reelin has no direct effect on cortical growth cones provides a strong argument for this view. The consequences of Reelin deficiency observed in vivo are likely to be indirect, secondary to the prof use laminar malformation of the reeler entorhinal cortex and hippocampus. Given the possible role of the recently described projections from hippocampal CR cells to the entorhinal cortex (Ceranik et al., 1999), it would certainly be interesting to study that projection in reeler mice. Finally, the action of Reelin on collateral branching should be studied further, for example using in vitro systems such as slice cultures in which the architecture of the tissue is better preserved and can be more accurately assessed than in explant cultures.

\section{REFERENCES}

Adams RH, Lohrum M, Klostermann A, Betz H, Püschel AW (1997) The chemorepulsive activity of secreted semaphorins is regulated by furin-dependent proteolytic processing. EMBO J 16:6077-6086.

Bar I, Goffinet AM (1999) Decoding the Reelin signal. Nature 399:645-646.

Borrell V, Del Rio JA, Alcantara S, Derer M, Martinez A, D'Arcangelo G, Nakajima K, Mikoshiba K, Derer P, Curran T, Soriano E (1999a) Reelin regulates the development and synaptogenesis of the layerspecific entorhino-hippocampal connections. J Neurosci 19:1345-1358.

Borrell V, Ruiz M, Del Rio JA, Soriano E (1999b) Development of commissural connections in the hippocampus of reeler mice: evidence of an influence of Cajal-Retzius cells. Exp Neurol 156:268-282.

Ceranik K, Deng J, Heimrich B, Lubke J, Zhao S, Forster E, Frotscher M (1999) Hippocampal Cajal-Retzius cells project to the entorhinal cortex: retrograde tracing and intracellular labelling studies. Eur J Neurosci 11:4278-4290.

Chédotal A, Del Rio JA, Ruiz M, He Z, Borrell V, de Castro F, Ezan F, Goodman CS, Tessier-Lavigne M, Sotelo C, Soriano E (1998) Sema- phorins III and IV repel hippocampal axons via two distinct receptors. Development 125:4313-4323.

Cooper JA, Howell BW (1999) Lipoprotein receptors: signaling functions in the brain? Cell 97:671-674.

D'Arcangelo G, Miao GG, Chen S, Soares HD, Morgan JI, Curran T (1995) A protein related to extracellular matrix proteins deleted in the mouse mutant reeler. Nature 374:719-723.

D’Arcangelo G, Nakajima K, Miyata T, Ogawa M, Mikoshiba K, Curran $T$ (1997) Reelin is a secreted glycoprotein recognized by the CR-50 monoclonal antibody. J Neurosci 17:23-31.

de Bergeyck V, Nakajima K, Lambert de Rouvroit C, Naerhuyzen B, Goffinet AM, Miyata T, Ogawa M, Mikoshiba K (1997) A truncated Reelin protein is produced but not secreted in the "Orleans" reeler mutation (Reln[rl-Orl]). Brain Res Mol Brain Res 50:85-90.

de Bergeyck V, Naerhuyzen B, Goffinet AM, Lambert de Rouvroit C (1998) A panel of monoclonal antibodies against reelin, the extracellular matrix protein defective in reeler mutant mice. J Neurosci Methods $82: 17-24$.

Deller T, Drakew A, Frotscher M (1999) Different primary target cells are important for fiber lamination in the fascia dentata: a lesson from reeler mutant mice. Exp Neurol 156:239-253.

Del Rio JA, Heimrich B, Borrell V, Forster E, Drakew A, Alcantara S, Nakajima K, Miyata T, Ogawa M, Mikoshiba K, Derer P, Frotscher M, Soriano E (1997) A role for Cajal-Retzius cells and reelin in the development of hippocampal connections. Nature 385:70-74.

Gosh A (1997) Axons follow Reelin routes. Nature 385:23-24.

Lambert de Rouvroit C, Goffinet AM (1998) The reeler mouse as a model of brain development. Adv Anat Embryol Cell Biol 150:1-106.

Lambert de Rouvroit C, de Bergeyck V, Cortvrindt C, Bar I, Eeckhout Y, Goffinet AM (1999) Reelin, the extracellular matrix protein deficient in reeler mutant mice, is processed by a metalloproteinase. Exp Neurol $156: 214-217$.

Lumsden AG, Davies AM (1983) Earliest sensory nerve fibres are guided to peripheral targets by attractants other than nerve growth factor. Nature 306:786-788.

Métin C, Deléglise D, Serafini T, Kennedy TE, Tessier-Lavigne M (1997) A role for netrin-1 in the guidance of cortical efferents. Development 124:5063-5074.

Toran-Allerand CD (1990) Long-term organotypic culture of central nervous system in Maximow assemblies. In: Methods in neurosciences, Vol 2, Cell culture (Conn PM, ed), pp 275-296. San Diego: Academic.

Trommsdorf M, Gotthardt M, Hiesberger T, Shelton J, Stockinger W, Nimpf J, Hammer RE, Richardson JA, Herz J (1999) Reeler/disabledlike disruption of neuronal migration in knockout mice lacking the VLDL receptor and ApoE receptor 2. Cell 97:689-701. 